\title{
PERSISTENCE IN CARBON FOOTPRINT EMISSIONS: AN OVERVIEW OVER \\ OF 92 COUNTRIES
}

\author{
Solarin Sakiru, Multimedia University, Malaka, Malaysia \\ Luis A. Gil-Alana, University of Navarra, Pamplona, Spain \\ Carmen Lafuente, University Francisco de Vitoria, Madrid, Spain
}

\begin{abstract}
The existing studies on persistence of ecological footprint have majorly concentrated on the aggregate ecological footprint without adequately considering its components. The aim of this paper is to contribute to the existing papers on ecological footprint by examining the persistence of carbon footprint emissions for a group of 92 countries. Unlike the extant papers, we use fractional integration, which allows us to consider the stationary $\mathrm{I}(0)$ and the nonstationary I(1) cases as particular models of interest, being therefore more general and flexible than these two classical representations. The results indicate that only 25 out of the 92 countries display mean reversion, with orders of integration strictly below 1 and showing transitory shocks, most of them belonging to lower-middle and low income countries. In these 25 countries it might not be easy to change the long run path of the carbon footprint as any policy shocks will have temporary effect. The foregoing findings can help policymakers in each nation to design efficient emission reducing policies.
\end{abstract}

Keywords: Carbon emissions; nonstationarity; unit roots; fractional integration JEL Classification: Q57; C22 


\section{Introduction}

One of the main obstacles to achieving sustainability is the biophysical confines of our planet. The Earth is essentially a closed system and therefore, it is subjected to thermodynamic laws which put restrictions on the production of natural resources as well as the absorption of waste. However, over the past five decades, humanity has, to a great extent, ensured that economic activities have continued to expand, whilst natural resources are gradually becoming limited (Mancini et al., 2016). Therefore, there is a need to use and analyse relevant tools to determine the degree at which mankind's demand surpasses or remains within the limits of what the Earth's natural capital can accommodate and to detect early warning signs and possibly project the impacts of human-driven pressures on ecosystems (Moldan et al., 2012). One of such tools is the carbon footprint. Generally, the carbon footprint is a component of the ecological footprint and it denotes the hectares of land needed to sequester anthropogenic carbon dioxide emissions. It accounts for more than $60 \%$ of the total ecological footprint in the globe (Global Footprint Network (2018).

Many aspects of the carbon footprint have not been adequately analysed in the literature including the stationarity of the series. There are several reasons why determining whether carbon footprint follows a nonstationary path or a stationary trend is important. First, the existence of unit roots means that shocks to carbon footprints arising from the deployment of more fuel-efficient transportation and equipment and resulting from energy price jumps or exogenous innovation will be permanent (McKitrick, 2007). Second, the nonstationarity of the carbon footprint series has vital implications for the Environmental Kuznets Curve (EKC) papers that have used the carbon footprint as a representative of pollution. The assumption of trend stationarity of the pollution indicators is present in some EKC studies (Sidneva and Zivot, 2014). However, an EKC study that uses a nonstationary carbon footprint series in levels as the dependent series is likely to suffer from spurious inference, when the 
explanatory variables such as output or income are also nonstationary. Specifically, if the time series for environmental indicator contain a stochastic trend, statistical approaches including ordinary least squares (OLS) that are based on the assumption that the series are stationary could generate spurious regression inferences. Therefore, the standard diagnostic statistics which are employed to gauge OLS results will suggest a statistically meaningful relation among non-stationary time series in most cases even when there is no relationship between the data generating processes (Hendry and Juselius, 2000; Dergiades et al., 2016). In the conventional autoregressive distributed lag (ARDL) method of Pesaran et al. (2001), it is assumed that all variables included in the regression involving environmental indicators should be at most stationary at first differences. Third, the division between trend stationary and difference stationary processes is vital to evaluate the potential long-term effect of environmental policy, which depends on the projection of future emissions and appraising the precision of these forecasts. For both nonstationary and stationary series, the long-term forecasts are the extrapolated deterministic trend. Forecast uncertainty for a nonstationary series increases as the forecast horizon becomes more distant. Stationary series are not susceptible to forecast uncertainty. Therefore, the long-term effects of a policy are less certain when the series are nonstationary relative to the stationary case (Gil-Alana and Solarin, 2018). Fourth, if the carbon footprint series at level are difference stationary, there is no prospect of convergence between them (as they are at different levels) so that any conclusion of convergence on the relative carbon footprint is at best weak (Nieswiadomy and Strazicich, 2004).

The literature on the stationarity of pollution indicators has predominantly focussed on per capita $\mathrm{CO}_{2}$ emissions (Christidou et al., 2013; Tiwari et al., 2016; Gil-Alana et al., 2017; Gil-Alana and Trani, 2018; etc.) However, per capita $\mathrm{CO}_{2}$ emissions and carbon footprint are different. Carbon footprint is expressed in terms of hectares of land, while per 
capita emissions is related to the total population of a country. Unlike the typical per capita emissions available in many databases, the carbon footprint incorporates goods that are imported into a country but are produced elsewhere and generally take into account emissions associated with international transport and shipping. Consequently, a nation's carbon footprint can rise even if the $\mathrm{CO}_{2}$ emissions within its borders decrease.

Our aim in this paper is to make two contributions to the literature on the stationarity of pollution series. First, we examine the stationarity of the carbon footprint in 92 countries, which is likely to offer novel information on an indicator that has been largely ignored in the literature. Our study is different from papers that have considered the stationarity of ecological footprints (Ulucak and Lin, 2017; Solarin and Bello, 2018; Ozcan et al., 2019; Yilanci et al., 2019). Both Solarin and Bello (2018) and Ozcan et al. (2019) have considered the ecological footprint but not the carbon footprint. Although Ulucak and Lin (2017) considered the carbon footprint, the focus was on the U.S and OCED. The features of carbon footprints vary across different countries and therefore, policies that are fit for the U.S and OECD might not necessarily be suitable for other countries. Hence, the results from the current exercises is likely to guide many countries on whether the policy makers should implement environmental policies to decrease carbon footprint or allow the internal dynamics of these countries to automatically address the increase in carbon footprint.

Our second contribution is the use of a fractional integration techniques, which according to our knowledge has not been used in the past to examine stationarity of carbon footprints or even ecological footprints. The fractional integration technique is appropriate in this context first because it generalizes the standard methods based on integer degrees of differentiation, allowing for fractional values. Thus, it allows for a much greater degree of flexibility in the dynamic specification of the data; Second, it can provide us with information 
about the nature of the shocks, being transitory if the order of integration is smaller than 1 , but permanent if that value is equal to or higher than 1 .

The remainder is arranged as follows: Section 2 reviews the existing literature, while the data and methodology of the paper are discussed in Section 3. The results are presented in Section 4. Section 5 concludes the paper.

\section{Literature review}

There is abundant literature on the stationarity and nonstationarity of $\mathrm{CO}_{2}$ emissions. Aldy (2006) and Lee and Chang (2009) show the convergence of the $\mathrm{CO}_{2}$ emissions of industrialized countries of the OECD, and the non-stability of the less developed countries using different methodologies, such as the Markov chain transition matrix and the panel data stationarity testing procedure developed by Carrion-i-Silvestre et al. (2005) respectively. Other studies have used unit root tests to check the convergence hypothesis by testing the stationarity/nonstationarity of the $\mathrm{CO}_{2}$ emissions. Examples are the works by Ezcurra (2007),

Panopoulou and Pantelidis (2009), Chang and Lee (2008), Romero-Ávila (2008), Lee et al. (2008), Yavuz and Yilanci (2013), Ahmed et al. (2016), and the conclusions obtained in these works are mixed.

The stationarity of the $\mathrm{CO}_{2}$ emissions has been established in Christidou et al. (2013). He finds evidence supporting stationarity for 33 countries covering the period 18702006 using a nonlinear panel unit root test developed by Kapetanios, Shin and Snell (KSS, 2003). Evidence of convergence on the per capita global carbon dioxide emissions is also found in Zhang et al. (2018). On the other hand, there is also a significant number of papers obtaining evidence in favour of the non-stationarity of $\mathrm{CO}_{2}$ emissions, some of the them focussing on the convergence of $\mathrm{CO}_{2}$ emissions between countries. Thus, for example, the study of Criado and Grether (2011) covers the time period 1960-2002, and they investigate 
the long run behaviour of the per capita $\mathrm{CO}_{2}$ emissions in a panel of 162 world areas, finding evidence in favour of nonstationarity, flattening and right-skewed spatial distributions before the oil price shocks in the 70s, and more stable and symmetric patterns between 1980 and 2000; in addition, other studies showing that $\mathrm{CO}_{2}$ emissions follow unit root processes include Herrerías (2013), Li and Lin (2013)) and Presno et al. (2018). In the same line, Jaunky (2011) shows that carbon dioxide emissions for high-income countries are integrated of order one, i.e. I(1). Yamazaki et al. (2014) also show that per capita $\mathrm{CO}_{2}$ emissions in OECD countries follow a unit root process.

Using fractional integration, Barros et al. (2016) study the global series of $\mathrm{CO}_{2}$ emissions and the series of each of its five components (gas, liquids, solids, cement production and gas flaring), as well global per capita emissions for a long span of data. They empirically show that the series are nonstationary with orders of integration significantly above 1. However, Belbute and Pereira (2017), using a smilar methodology, conclude that the aggregate world $\mathrm{CO}_{2}$ emissions and its five components are stationary and mean reverting, though exhibiting long-term memory patterns.

Ecological Footprint (EF) is another environmental indicator that aroused the interest of researchers. Ulukak and Apergis (2018) investigate the convergence of the per capita ecological footprint using the club clustering methodological approach for the case of the EU countries; Jia et al., (2010) improve the forecasting capacity of the EF indicator with the standard AutoRegressive Integrated Moving Average (ARIMA) model; Solarin and Bello (2018) also showed the nonstationarity of EF. On the other hand, Ozcan et al. (2019), using unit root tests and SPSM procedures, find stationarity of EF for all high income countries and for about the half of the low-income and upper-middle income countries, while nonstationarity is found for the lower-middle income economies. 
Few studies have focused on the carbon footprint. We only found studies of the carbon footprint in research on EF analyzed in its components. Ulucak and Lin (2017) analyzed the stochastic behaviour of the EF and its components (carbon footprint, cropland, grazing land, forest products, built-up-land, and fishing grounds) for the U.S. Using Fourier unit root tests, they conclude that the cropland footprint and biocapacity are stationary, whereas the ecological footprint, carbon footprint, grazing land footprint, forest footprint, built-up land footprint, fishing grounds footprint, and ecological deficit are nonstationary. Yilanci et al. (2019), using a technique developed by Bahmani-Oskooee et al. (2014), study the unit root properties of the ecological footprint and its six components using panel data from 25 OECD countries for the time period 1961-2013. Their results indicate that five EF components show stationary properties, but the footprint of fishing grounds does not have mean-reverting behavior. Solarin and Bello (2018) have provided evidence for nonstationarity of the Ecological Footprint, while Ozcan et al. (2019) conclude that the series is stationary.

From the above literature, something that is apparent is the last of consensus about the stationary/nonstationary nature of the $\mathrm{CO}_{2}$ emissions including carbon footprint. However, all except two of these works (Barros et al., 2016, and Belbute and Pereira, 2017) use techniques that characterizes the series as stationary $\mathrm{I}(0)$ or nonstationary $\mathrm{I}(1)$, not allowing for fractional degrees of differentiation, which is the approach used in this work. As later explained, in Section 3.2, this method (fractional integration) is more general than the classical ones, including the $\mathrm{I}(0)$ and the $\mathrm{I}(1)$ models as particular cases of interest within this methodology.

\section{Data and methodology}

\subsection{Carbon footprint}


Carbon footprint is calculated by utilising several parameters, namely domestic electricity consumption and the combustion of fossil fuels, embodied carbon in traded items, a country's contribution to the world's international transport emissions and also non-fossil fuel sources of emissions (National Footprint Accounts, 2016). The total amount of $\mathrm{CO}_{2}$ emissions apportioned to a particular country is expressed in global hectares terms by using the footprint intensity of carbon. The carbon footprint is derived from the following:

$$
C F=\frac{P_{C^{*}}\left(1-S_{O C E A N}\right)}{Y_{C}} * E Q F_{C} * I Y F_{C},
$$

where $C F$ is the carbon footprint of a country; $P_{C}$ is the yearly anthropogenic $\mathrm{CO}_{2}$ emissions; $S_{\text {OCEAN }}$ is the share of carbon that is taken by the oceans; $Y_{C}$ is the yield of the productive land that is needed to capture the $\mathrm{CO}_{2}$ emissions; $E Q F_{C}$ is an equivalence term for carbon as a land type. $I Y F_{C}$ is an adjustment term for temporal variations in yield from the forest.

We generated the annual dataset of carbon footprint in per capita global hectares and its components from the database of the Global Footprint Network (2018). We concentrate on 92 countries for the period 1961 to 2014 being the only countries which have a dataset available for the entire period. ${ }^{1}$

\subsection{Methodology}

As mentioned earlier, we use techniques based on fractional integration. For this purpose we need to define first an integrated of order 0 or $I(0)$ process. We say that a given process $\left\{u_{t}, t\right.$ $=0, \pm 1, \ldots\}$ is $\mathrm{I}(0)$ if the infinite sum of its autocovariances is finite. Within this group we can include the white noise and the stationary and invertible ARMA processes. Having said this, a process $\left\{x_{t}, t=0, \pm 1, \ldots\right\}$ is integrated of order $d$ (and denoted as $I(d)$ ) if taking its $d$ differences the process becomes I(0). That is,

\footnotetext{
${ }^{1}$ See Appendix 1 for the abbrevations of the countries across the tables
} 


$$
(1-L)^{d} x_{t}=u_{t}, \quad t=1,2, \ldots,
$$

where $\mathrm{L}$ is the lag operator (i.e., $\mathrm{Lx}_{\mathrm{t}}=\mathrm{x}_{\mathrm{t}-1}$ ); $\mathrm{d}$ can be any real value (and thus allowing for fractional values), and $\mathrm{u}_{\mathrm{t}}$ is $\mathrm{I}(0)$ as defined above. Then, the polynomial on the left hand side in (2) can be expressed in terms of its Binomial expansion, such that, for all real d:

$$
(1-L)^{d}=\sum_{j=0}^{\infty} \psi_{j} L^{j}=\sum_{j=0}^{\infty}\left(\begin{array}{l}
d \\
j
\end{array}\right)(-1)^{j} L^{j}=1-d L+\frac{d(d-1)}{2} L^{2}-\ldots,
$$

and thus:

$$
(1-L)^{d} x_{t}=x_{t}-d x_{t-1}+\frac{d(d-1)}{2} x_{t-2}-\ldots
$$

In this context, d plays a crucial role, since it will be an indicator of the degree of dependence of the series. Thus, the higher the value of $\mathrm{d}$ is, the higher the level of association will be between the observations. These processes were introduced in the 80 s by Granger (1980, 1981), Granger and Joyeux (1980) and Hosking (1981) and the first applications with aggregate data appear in the 90s (Sowell, 1992; Baillie, 1996; Gil-Alana and Robinson, 1997; etc.). Nowadays, they are widely applied in many different disciplines including in environmental studies (Solarin et al., 2018; Barassi et al., 2018; etc.). Note that they are very flexible in the sense that depending on the value of $d$ we can characterize different processes such as anti-persistence $(\mathrm{d}<0)$, short memory or $\mathrm{I}(0)$ behaviour $(\mathrm{d}=0)$; stationary long memory processes $(0<\mathrm{d}<0.5)$, nonstationary though mean reverting behaviour $(0.5 \leq \mathrm{d}<$ $1)$; unit roots or $\mathrm{I}(1)(\mathrm{d}=1)$ or even explosive models $(\mathrm{d}>1)$. Moreover, $\mathrm{d}$ plays a crucial role in the determination of the nature of the shocks, noting that if $\mathrm{d}$ is smaller than 1 shocks will have a transitory nature contrary to what happens if $d \geq 1$ where shocks will be permanent.

We estimate the differencing parameter $\mathrm{d}$ by using the Whittle function in the frequency domain (Dahlhaus, 1989). In particular, we use a testing approach developed by 
Robinson (1994) that is very convenient in the context of the present paper. It is a Lagrange Multiplier (LM) test that is based on the following model,

$$
y_{t}=\beta^{T} z_{t}+x_{t}, \quad t=1,2, \ldots,
$$

where $\mathrm{y}_{\mathrm{t}}$ is the observed data, $\mathrm{z}_{\mathrm{t}}$ is a $(\mathrm{kx} 1)$ vector of deterministic terms that might include for instance, an intercept and time trends, and the regressions errors $\mathrm{x}_{\mathrm{t}}$ are of the same for as in equation (1) and thus, potentially fractional. The tested null hypothesis is:

$$
H_{o}: d=d_{0}
$$

in (3) and (1) for any real value $d_{0}$. As earlier mentioned, the test has several advantages: Firstly, it is valid for any real value $\mathrm{d}_{0}$, and thus, including stationary $\left(\mathrm{d}_{0}<0.5\right)$ but also nonstationary $\left(\mathrm{d}_{0} \geq 0.5\right)$ hypotheses, with no need of preliminary differencing in the latter case; also, the limiting distribution is standard normal, and thus, we do not need to rely on numerical values obtained by Monte Carlo simulation studies as is the case with most unit root procedures; moreover, this limit behaviour holds independently of the deterministic terms used in (3) and the way of modelling the $I(0)$ disturbances $u_{t}$ in (1); finally, the test is the most efficient one in the Pitman sense against local departures from the null. The functional form of the test statistic can be found in Gil-Alana and Robinson (1997).

\section{Empirical results}

As a preliminary step in this section, we conduct standard unit root methods on the 92 series. We use Dickey and Fuller (ADF, 1979) and Elliot et al. (ERS, 1996) tests, and the results, though not reported, produced evidence in favour of unit roots in the majority of the cases. We start this empirical section by considering the following model, This, however, is not surprising, noting that these methods, along with others like Kwiatkowski et al., (KPSS, 1992), Phillips and Perron (PP, 1988); Ng and Perron (NP, 2001) focus exclusively on the $\mathrm{I}(0) / \mathrm{I}(1)$ dichotomy and do not consider fractional alternatives. Moreover, it is a well known 
fact that all these unit root methods have extremely low power if the alternatives are of a fractional form. (See, e.g., Diebold and Rudebusch, 1991; Hassler and Wolters, 1994; Lee and Schmidt, 1996; etc.). Due to that, we start this section by considering the following model,

$$
y_{t}=\alpha+\beta t+x_{t}, \quad(1-L)^{d_{o}} x_{t}=u_{t}, \quad t=1,2, \ldots
$$

where $y_{t}$ is the time series we observe, $\alpha$ and $\beta$ are the coefficients referring respectively to the intercept and the time trend, and $\mathrm{d}$ is the differencing parameter.

Table 1 displays the estimated values of $d$ (and the 95\% confidence bands of the nonrejection values of d using Robinson's (1994) tests, under the three standard cases of i) no deterministic terms, ii) an intercept, and iii) an intercept with a linear time trend. We have marked in bold in the table the selected model for each series.

\section{[Insert Tables 1 and 2 about here]}

We observe that the time trend is required in a number of cases (33 countries summarized in Table 3), while an intercept is sufficient to describe the deterministic part in the rest of the countries. Along with the estimated values of d, we also report the $95 \%$ confidence intervals of the non-rejection values of d using Robinson's (1994) approach. Table 2 focusses on the estimated coefficients for each country. The second column displays the estimates of $\mathrm{d}$, and columns 3 and 4 report the intercept and the time trend coefficients.

A summary of the results is presented across Tables 3 and 4 . In Table 3 we display the list of countries that show significant time trends. We observe that the highest coefficient corresponds to South Korea, followed by Malaysia, Austria and Israel. We have included in the table a column with a number referring to the income level: 1 for high income countries, 2 for upper-middle income, 3 for lower-middle income, and 4 for low income countries. (See Appendix 2 for the classification of the countries). We observe in Table 3 that most of the countries displays time trends refers to categories 3 and 4 . 


\section{[Insert Tables 3 and 4 about here]}

Table 4 summarizes the results in Table 2 in terms of the estimated values of d. We present the results grouped in three different categories. The first group refers to the countries belonging to the "mean reversion" case, i.e,. countries with an order of integration significantly smaller than 1 ; the second group refers to those countries showing evidence of unit roots, i.e., with orders of integration around 1; and the third group refers to countries with explosive behaviour and orders of integration significantly above 1 . We observe that dealing with the "mean reverting" countries, most of them belong to category 4 (low income countries), and just the opposite happens to the group of "explosive" behaviour, with most countries belonging to category 1 (high income countries). Thus, it seems that the degree of persistence seems to be highly correlated with the income level of the countries, and those with the lowest income are related to lower degrees of persistence.

\section{Concluding comments}

In this paper we have examined the stationary/nonstationary properties of the carbon footprint emissions in a group of 92 countries for the time period 1961 - 2014. For this purpose, we have used techniques based on the concept of fractional integration which is more general than the standard methods based on integer degrees of differentiation ( 0 for stationarity and 1 for nonstationarity). Allowing the order of integration to be fractional allows us to study cases of nonstationarity though with mean reverting behaviour if the differencing parameter is in the interval $[0.5,1)$.

Our results reject the hypothesis of stationarity $\mathrm{I}(0)$ in all cases, but also the $\mathrm{I}(1)$ hypothesis is rejected in many countries, finding evidence of mean reversion $(d<1)$ in some countries, and evidence of explosive behaviour $(\mathrm{d}>1)$ in others. Thus, the use of classical methods based on the strong $\mathrm{I}(0) / \mathrm{I}(1)$ dichotomy may produce erroneous conclusions on the 
properties of the series. We show that only 25 out of the 92 countries show mean reversion, most of them belonging to lower-middle income (7) or low income (10) countries. The mean reversion in these countries implies that shocks to the carbon footprint are temporary. Carbon footprint will move back towards its initial mean or trend after experiencing a natural or economic shock. Hence, policy makers should not use excessive targets when the carbon footprint momentarily departs from the trend path as environmental management and conservation policies aimed at decreasing the carbon footprint do not have no durable effects. The internal dynamics of these economies will tend to offer some hindsight to revert back carbon footprint to its initial trend path. Hence, excessive interferences from the political authorities will be a misfit under this scenario.

On the other extreme, the highest degrees of persistence are observed in high income countries. Economic or natural shock hitting carbon footprint will have long-lasting effects as carbon footprint not be able to move back to its original trend mean or path or after such shock.

Thus, the authorities in these economies should introduce environmental programmes to decrease the footprint arising from the human activities. These strategies include the imposing of carbon tax to thwart carbon overuse and subsidies provision for the use of green energy sources. As the industrialized economies have developed better strategies to address the problems of carbon footprint; developing nations should imitate the steps that have been taken by the advanced nations.

One of the limitations of this study is that we have not considered the other elements of ecological footprints. Beyond the carbon footprint, the aggregate ecological footprint has five more components, which include fishing grounds, cropland, forest land and built-up land grazing land footprints. Hence, future studies can take up the challenge of examining the persistence of the other subsets of ecological footprint, which will provide more insights on 
ecological footprint dynamics for each country that has been covered in this paper. In addition, the possibility of structural breaks is an issue that has not been considered in this work. This is relevant, noting that various authors have shown that fractional integration and structural breaks are intimately related (Dibold and Inoue, 2001; Granger and Hyung, 2004; etc.) and though many methods have been proposed in recent years (Sibbertsen, 2004; GilAlana, 2008; Hassler and Meller, 2011; Shao, 2011; Hyang and Shin, 2018; etc.) this is something that will be examined in future papers. 


\section{References}

Ahmed, M., Khan, A.M. Bibi, S. And Zakaria, M. (2016). Convergence of per capita CO2 emissions across the globe: Insights via Wavelet analysis. Renewable and Sustainable Energy Reviews. http://doi.org/10.1016/j.rser.2016.10.053.

Aldy, J.E. (2006) Per capita carbon dioxide emissions: convergence or divergence? Environmental Resource Economics 33, 533-555.

Bahmani-Oscooee, M, Chang, T. And Wu, T (2014). Revisiting purchasing power parity in African countries: panel stationary test with sharp and smooth breaks. Applied Financial Economics. Volume 24, issue 22, 1429-1438.

Baillie, R.T. (1996). Long memory processes and fractional integration in econometrics, Journal of Econometrics, 73(1), 5-59.

Barassi, M.R., N. Spagnolo and Y. Zhao, (2018), Fractional integration versus structural change- Testing the convergence of $\mathrm{CO} 2$ emissions, Environmental and Resource Economics 71, 4, 923-968.

Barros, C.P., Gil-Alana, L.A. and De Gracia, F.P. (2016). Stationarity and long range dependence of carbon dioxide emisssions: evidence for disaggregated data. Environmental Resource Economics 63(1), 45-56.

Belbute, J.M. and Pereira, A.M. (2017). Do global CO2 emissions from fossil-fuel consuption exhibit long memory? A fractional-integration anaysis. Applied Economics, 1-16. http:/doi.org/10.1080/000368446.2016.1273508.

Carlino, G. A., and Mills, L. O. (1993). Are US regional incomes converging?: A time series analysis. Journal of Monetary Economics, 32(2), 335-346.

Carrion-i-Silvestre, J.L, Barrio-Castro, T.D. and Lopez-Bazo, E. (2005), Breaking the panels: an application to the GDP per capita, Econometrics Journal 8, 1591-75.

Chang C.P. and Lee C.C. (2008). Are per capita carbon dioxide emissions converging among industrialized conuntries? New time series evidence with structural breaks. Environmental and Resource Economics, 13(4), 497-515

Christidou, M., Panagiotidis, T., and Sharma, A. (2013). On the stationarity of per capita carbon dioxide emissions over a century. Economic Modelling, 33, 918-925.

Criado CO. and Grether, JM. (2011). Convergence in per capita CO2 emissions: a robust distributional approach. Resources Energy Economics, 33(3),637-65.

Dahlhaus, R., 1989, Efficient parameter estimation for self-similar processes, Annals of Statistics 17, 1749-1766.

Dergiades, T., Kaufmann, R. K., and Panagiotidis, T. (2016). Long-run changes in radiative forcing and surface temperature: The effect of human activity over the last five centuries. Journal of Environmental Economics and Management, 76, 67-85. 
Dickey, D.A and Fuller, W. A. (1979) Distributions of the estimators for autoregressive time series with a unit root, Journal of American Statistical Association, 74 (366), 427-481.

Diebold, F.X. and A. Inoue (2001)."Long Memory and Regime Switching“. Journal of Econometrics, 105, 131-159

Diebold, F.X. and Rudebusch, G.D. (1991) 'On the power of Dickey-Fuller test against fractional alternatives', Economics Letters 35, 1, 155-160.

Elliot, G., T.J. Rothenberg, and J.H. Stock, (1996), Efficient tests for an autoregressive unit root, Econometrica 64, 813-836.

Ezcurra, R. (2007). Is there cross-country convergence in carbon dioxide emissionas? Energy Policy 35, 1363-1372.

Gil-Alana, L.A. (2008), Fractional integration and structural breaks at unknown periods of time, Journal of Time Series Analysis 29,1,163-185.

Gil-Alana, L. A., Cunado, J., and Gupta, R. (2017). Persistence, Mean-Reversion and Nonlinearities in CO2 Emissions: Evidence from the BRICS and G7 Countries. Environmental and Resource Economics, 67(4), 869-883.

Gil-Alana, L.A. and Robinson, P.M. (1997), Testing of unit roots and other nonstationary hypotheses in macroeconomic time series, Journal of Econometrics 80(2), 241-268.

Gil-Alana, L. A., and Solarin, S. A. (2018). Have US environmental policies been effective in the reduction of US emissions? A new approach using fractional integration. Atmospheric Pollution Research, 9(1), 53-60.

Gil-Alana, L. A., and Trani, T. (2018). Time Trends and Persistence in the Global CO 2 Emissions Across Europe. Environmental and Resource Economics, 1-16.

Global Footprint Network (2018). Global foot print network database. Available at http://data.footprintnetwork.org/countryTrends.html

Granger, C.W.J. (1980) Long Memory Relationships and the Aggregation of Dynamic Models, Journal of Econometrics, 14, 227-238.

Granger, C.W.J. (1981), Some properties of time series data and their use in econometric model specification, Journal of Econometrics 16, 121-130.

Granger, C.W.J. and R. Joyeux, (1980), An introduction to long memory time series models and fractional differencing, Journal of Time Series Analysis 1, 15-39.

Granger, C.W.J. and N. Hyung (2004), "Occasional Structural Breaks and Long Memory with an Application to the S\&P 500 Absolute Stock Return", Journal of Empirical Finance, 11, 399-421.

Hassler, U. and B. Meller, 2011, Detecting multiple breaks in long memory. The case of US inflation, Discussion Paper Series 1. Economic Studies 26, Deutsche Bundesbank. 
Hasslers, U. and Wolters, J. (1994) 'On the power of unit root tests against fractional alternatives', Economics Letters 45, 1, 1-5.

Hendry, D. F., and Juselius, K. (2000). Explaining cointegration analysis: The Energy Journal, 21(1), 1-42.

Herrerias, M.J.(2013). The environmental convergence hypothesis: carbon dioxide emissionas according to the source of energy. Energy Policy, 61, 1140-1150.

Hosking, J.R.M. (1981). Fractional differencing, Biometrika, 68, 165-176.

Hyang, E. and D.W. Shin, 2018, Tests for structural breaks in memory parameters of long memory heterogeneous autoregressive models, Communications in Statistics, Theory and Models 47, 21.

Jaunky, V.(2011). The CO2 emissions-income nexus:evidence from rich countries. Energy Policy, 39, 1228-1240.

Jia, J., Zhao, J., Deng, H. and Duan J. (2010).Ecological footprint simulation and prediction by ARIMA model - a case study in Henan Province of China. Ecological Indicators, 10, 538-544.

Kapetanios, G., Shin, Y., and Snell, A. (2003). Testing for a unit root in the nonlinear STAR framework. Journal of Econometrics 112(2), 359-379.

Kwiatkowski D, P.C.D Phillips, P. Schmidt, Y. Shin, (1992), Testing the null hypothesis of stationarity against the alternative of a unit root: How sure are we that economic time series have a unit root?, Journal of Econometrics 54, 159-178.

Lee, C.C. and Chang, C.P.(2009). Stochastic convergence of per capita carbon dioxide emisssions and multiple structural breaks in OECD conuntries. Economic Modelling 26(6):1375-81.

Lee, D. and Schmidt, P. (1996) 'On the power of the KPSS test of stationarity against fractionally integrated alternatives', Journal of Econometrics 73, 1, 285-302.

Lee, C.C., Chang, C.P. and Chen, P.F.(2008). Do CO2 emissions levels converge among 21 OECD countries? New evidence from unit root structural break tests. Applied Economics Letters 15(7): 551-6.

Li, X. and Lin, B. (2013). Global convergence in per capita CO2 emissions. Renewable Sustainable Energy Review 24: 357-63.

Mancini, M. S., Galli, A., Niccolucci, V., Lin, D., Bastianoni, S., Wackernagel, M., and Marchettini, N. (2016). Ecological footprint: refining the carbon footprint calculation. Ecological Indicators, 61, 390-403.

McKitrick, R. (2007). Why did US air pollution decline after 1970?. Empirical Economics, 33(3), 491-513. 
Moldan, B., Janoušková, S., and Hák, T. (2012). How to understand and measure environmental sustainability: Indicators and targets. Ecological Indicators, 17, 4-13.

National Footprint Accounts (2016). Working Guidebook to the National Footprint Accounts: 2016. Available at

http://www.footprintnetwork.org/content/documents/National_Footprint_Accounts_2016_Gu idebook.pdf

Nieswiadomy, M. L., and Strazicich, M. C. (2004). Are political freedoms converging?. Economic Inquiry, 42(2), 323-340.

Ng, S. and P. Perron,. (2001), Lag length selection and the construction of unit root tests with good size and power, Econometrica 69, 519-1554

Ozcan, B., Ulucak, R., and Dogan, E. (2019). Analyzing long lasting effects of environmental policies: Evidence from low, middle and high income economies. Sustainable Cities and Society, 44, 130-143.

Panopoulou, E., and Pantelidis, T. (2009). Club convergence in carbon dioxide emissions. Environmental and Resource Economics, 44(1), 47-70.

Pesaran, M. H., Shin, Y. and Smith, R. J. (2001). Bounds testing approaches to the analysis of level relationships. Journal of Applied Econometrics, 16(3), 289-326.

Phillips, P.C.B. and P. Perron, (1988), Testing for a unit root in time series regression, Biometrika 75, 335-346.

Presno, M.J., Landajo, M. and Fernández González, P.(201). Stochastic convergence in per capita CO2 emissions. An approach from nonlinear stationarity analysis. Energy Economics 70, 563-581.

Robinson, P., 1994, Efficient tests of nonstationary hypotheses, Journal of the American Statistical Association 89, 1420-1437.

Romero-Ávila, D. (2008). Convergence in cabon dioxide emissions among industrialised countries revisited. Energy Economics, 30(5), 2265-2282.

Shao, X. (2011). A simple test of changes in mean in the possible presence of long-range dependence. Journal of Time Series Analysis, 32, 598-606

Sibbertsen, P., 2004, Long memory versus structural breaks. An overview, Statistical Papers $45,4,465-515$.

Sidneva, N., and Zivot, E. (2014). Evaluating the impact of environmental policy on the trend behavior of US emissions of nitrogen oxides and volatile organic compounds. Natural Resource Modeling, 27(3), 311-337. 
Solarin, S.A., L.A. Gil-Alana and U. Al-mulali (2018). Stochastic convergence of renewable energy consumption in OECD countries: a fractional integration approach, Environmental Science and Pollution Research 25, 4.

Solarin, S. A., and Bello, M. O. (2018). Persistence of policy shocks to an environmental degradation index: The case of ecological footprint in 128 developed and developing countries. Ecological Indicators, 89, 35-44.

Sowell, F.B., 1992, Modeling long run behavior with the fractional ARIMA model, Journal of Monetary Economics 29, 277-302

Tiwari, A. K., Kyophilavong, P., and Albulescu, C. T. (2016). Testing the stationarity of CO2 emissions series in Sub-Saharan African countries by incorporating nonlinearity and smooth breaks. Research in International Business and Finance, 37, 527-540.

Ulucak, R. And Apergis, N. (2018).Does convergence really matter for the environment? An application based on club convergence and on the ecological footprint concept for the EU countries. Environmental Science and Policy, 80, 21-27

Ulucak, R., and Lin, D. (2017). Persistence of policy shocks to Ecological Footprint of the USA. Ecological Indicators, 80, 337-343.

Yamazaki, S., Tian, J. and Doko Tchatoka, F. (2014). Are per capita CO2 emissions increasing among OECD countries? a test of trends and breaks. Applied Economic Letters 21(8), $569-72$.

Yavuz, N. C. and Yilanci, V. (2013). Convergence in per capita carbon dioxide emissions among countries: a TAR panel unit root approach. Environmental and Resource Economics 54(2),283-91.

Yilanci, V., M.S. Gorus and M. Aydin, (2019). Are shocks to ecological footprint in OECD countries permanent or temporary?, Journal of Cleaner Production 212, 270-301.

Zhang, Z., X. Zou, Q. Song, T. Wang and G. Fu, (2018), Analysis of the global carbon dioxide emissions from 2003 to 2015: convergence trends and regional contributions, Carbon Management 9, 1, 45-55. 
Table 1: Estimates of $d$ for each series

\begin{tabular}{|c|c|c|c|}
\hline Country & No det. terms & With an intecept & With a linear trend \\
\hline AFG & $1.18(1.02,1.42)$ & $1.21(1.03,1.46)$ & $1.21 \quad(1.03,1.47)$ \\
\hline ALB & $1.04(0.87,1.30)$ & $1.22(1.04,1.48)$ & $1.22(1.03,1.48)$ \\
\hline ANG & $1.07 \quad(0.85,1.37)$ & $1.04(0.78,1.35)$ & $1.05(0.84,1.35)$ \\
\hline ARG & $0.97 \quad(0.82,1.18)$ & $1.00(0.81,1.27)$ & $1.00 \quad(0.82,1.27)$ \\
\hline AUS & $0.87 \quad(0.70,1.10)$ & $1.11(0.90,1.40)$ & $1.11(0.89,1.39)$ \\
\hline AUSTRIA & $0.81 \quad(0.56,1.09)$ & $0.83(0.67,1.13)$ & $0.83 \quad(0.62,1.13)$ \\
\hline BAR & $0.59 \quad(0.42,0.87)$ & $0.70 \quad(0.59,0.89)$ & $0.68 \quad(0.51,0.89)$ \\
\hline BEL & $0.99 \quad(0.82,1.22)$ & $0.97(0.80,1.20)$ & $0.98 \quad(0.81,1.19)$ \\
\hline BEN & $1.04(0.85,1.37)$ & $1.04(0.86,1.37)$ & $1.04(0.84,1.38)$ \\
\hline BOL & $0.67 \quad(0.55,0.82)$ & $0.67 \quad(0.57,0.81)$ & $0.62(0.48,0.80)$ \\
\hline BRA & $1.10(0.93,1.32)$ & $1.13(0.93,1.37)$ & $1.13(0.94,1.37)$ \\
\hline BUR & $0.70 \quad(0.56,0.87)$ & $0.67 \quad(0.51,0.90)$ & $0.66(0.50,0.90)$ \\
\hline BURK & $0.94 \quad(0.80,1.17)$ & $0.98 \quad(0.82,1.33)$ & $0.97 \quad(0.79,1.36)$ \\
\hline CAM & $1.07(0.93,1.29)$ & $1.09(0.92,1.34)$ & $1.08 \quad(0.93,1.33)$ \\
\hline CAN & $1.01(0.86,1.23)$ & $1.21(1.02,1.48)$ & $1.20(1.02,1.45)$ \\
\hline CAR & $0.71 \quad(0.55,0.94)$ & $0.62(0.47,0.81)$ & $0.62(0.47,0.81)$ \\
\hline CHAD & $0.82(0.70,0.99)$ & $0.79 \quad(0.65,0.96)$ & $0.79 \quad(0.67,0.96)$ \\
\hline CHILE & $0.90 \quad(0.79,1.06)$ & $0.99(0.86,1.22)$ & $0.99 \quad(0.84,1.24)$ \\
\hline CHINA & $1.20(1.11,1.36)$ & $1.48(1.31,1.76)$ & $1.50(1.35,1.73)$ \\
\hline $\mathrm{COL}$ & $1.03(0.86,1.26)$ & $0.90 \quad(0.52,1.22)$ & $0.93 \quad(0.73,1.21)$ \\
\hline CONGO & $0.75 \quad(0.63,0.91)$ & $0.70 \quad(0.57,0.87)$ & $0.69(0.57,0.87)$ \\
\hline CORD & $1.00(0.87,1.20)$ & $1.00(0.84,1.23)$ & $1.00 \quad(0.84,1.23)$ \\
\hline COSR & $0.47 \quad(0.34,0.71)$ & $0.55(0.45,0.71)$ & $0.46 \quad(0.29,0.69)$ \\
\hline COTI & $1.15(1.02,1.34)$ & $1.17(1.02,1.39)$ & $1.17 \quad(1.02,1.38)$ \\
\hline
\end{tabular}

(cont.) 


\begin{tabular}{|c|c|c|c|}
\hline Country & No det. terms & With an intecept & With a linear trend \\
\hline CUBA & $1.09(0.94,1.35)$ & $1.26(1.05,1.62)$ & $1.25(1.05,1.61)$ \\
\hline DOMR & $0.88(0.64,1.20)$ & $0.91(0.71,1.23)$ & $0.90(0.67,1.23)$ \\
\hline DEN & $1.07(0.90,1.33)$ & $1.02(0.85,1.33)$ & $1.02(0.85,1.31)$ \\
\hline ESAL & $0.91(0.77,1.12)$ & $0.92(0.81,1.12)$ & $0.91(0.77,1.12)$ \\
\hline FIJ & $0.79(0.58,1.04)$ & $0.51 \quad(0.36,0.85)$ & $0.65(0.45,0.90)$ \\
\hline FRA & $0.98 \quad(0.83,1.18)$ & $1.08(0.90,1.31)$ & $1.08(0.90,1.30)$ \\
\hline GAM & $0.72(0.49,1.20)$ & $0.74(0.61,1.03)$ & $0.74(0.55,1.03)$ \\
\hline GER & $1.02(0.88,1.22)$ & $1.10(0.95,1.33)$ & $1.10(0.95,1.32)$ \\
\hline GHA & $0.86(0.73,1.05)$ & $0.84(0.72,1.04)$ & $0.83(0.69,1.04)$ \\
\hline GRE & $1.06(0.88,1.29)$ & $1.11(0.96,1.30)$ & $1.10(0.96,1.29)$ \\
\hline GUA & $0.68(0.59,0.93)$ & $0.80(0.71,1.03)$ & $0.62(0.33,1.01)$ \\
\hline GUI & $0.95(0.80,1.23)$ & $0.92(0.76,1.23)$ & $0.92(0.76,1.23)$ \\
\hline GUY & $0.88 \quad(0.76,1.04)$ & $0.86(0.71,1.07)$ & $0.86(0.71,1.07)$ \\
\hline HAI & $0.65(0.45,1.05)$ & $0.68 \quad(0.58,0.88)$ & $0.56(0.34,0.87)$ \\
\hline IND & $1.23(1.10,1.44)$ & $1.25(1.16,1.39)$ & $1.29(1.19,1.43)$ \\
\hline INDO & $0.83(0.74,1.06)$ & $0.83(0.76,0.97)$ & $0.75(0.60,0.98)$ \\
\hline ISR & $0.50 \quad(0.39,0.84)$ & $0.94(0.71,1.75)$ & $0.90(0.49,1.78)$ \\
\hline ITA & $1.01(0.82,1.27)$ & $1.18(1.02,1.41)$ & $1.17(1.01,1.39)$ \\
\hline JAP & $1.09(0.94,1.29)$ & $1.20(1.03,1.44)$ & $1.18(1.03,1.41)$ \\
\hline JOR & $0.88(0.64,1.22)$ & $0.91(0.71,1.26)$ & $0.90(0.64,1.26)$ \\
\hline KDPR & $1.17(1.04,1.35)$ & $1.23(1.11,1.40)$ & $1.22(1.10,1.38)$ \\
\hline KEN & $1.00(0.85,1.21)$ & $0.98(0.79,1.24)$ & $0.98 \quad(0.81,1.24)$ \\
\hline KOR & $0.81 \quad(0.73,0.97)$ & $0.85 \quad(0.77,1.01)$ & $0.77 \quad(0.60,0.99)$ \\
\hline LAO & $0.71(0.45,1.01)$ & $0.51 \quad(0.34,0.86)$ & $0.52(0.26,0.87)$ \\
\hline LEB & $0.94(0.73,1.22)$ & $1.02(0.82,1.30)$ & $1.01(0.83,1.29)$ \\
\hline LIB & $0.82(0.66,1.04)$ & $0.77(0.60,1.03)$ & $0.77(0.59,1.03)$ \\
\hline LUX & $0.79(0.63,1.02)$ & $0.72(0.56,0.93)$ & $0.72(0.57,0.93)$ \\
\hline
\end{tabular}

(cont.) 


\begin{tabular}{|c|c|c|c|}
\hline Country & No det. terms & With an intecept & With a linear trend \\
\hline MAD & $0.79(0.63,1.05)$ & $0.49 \quad(0.32,0.81)$ & $0.50 \quad(0.31,0.81)$ \\
\hline MAL & $0.81(0.72,0.98)$ & $0.82(0.73,0.98)$ & $0.75(0.60,0.97)$ \\
\hline MALI & $1.01 \quad(0.88,1.22)$ & $0.99 \quad(0.87,1.18)$ & $1.00(0.86,1.20)$ \\
\hline MALTA & $0.83(0.70,1.01)$ & $0.86(0.74,1.02)$ & $0.86(0.74,1.02)$ \\
\hline MEX & $0.34 \quad(0.28,1.01)$ & $0.53(0.46,0.64)$ & $0.33(0.16,0.55)$ \\
\hline MOZ & $0.78 \quad(0.67,0.92)$ & $0.75(0.64,0.90)$ & $0.74 \quad(0.63,0.89)$ \\
\hline MYAN & $1.59(1.30,1.93)$ & $1.49(0.59,1.94)$ & $1.45(0.89,1.93)$ \\
\hline NEP & $0.82(0.71,0.98)$ & $0.80 \quad(0.70,0.95)$ & $0.77 \quad(0.64,0.95)$ \\
\hline NETH & $0.92(0.76,1.15)$ & $0.77 \quad(0.58,1.01)$ & $0.79(0.63,1.01)$ \\
\hline NIC & $0.76(0.59,0.98)$ & $0.63(0.49,0.87)$ & $0.66(0.48,0.88)$ \\
\hline NIG & $0.92(0.79,1.09)$ & $0.87(0.73,1.04)$ & $0.88(0.76,1.04)$ \\
\hline NIGE & $1.12(0.87,1.47)$ & $1.21(0.97,1.57)$ & $1.21(0.96,1.57)$ \\
\hline NOR & $0.98 \quad(0.82,1.23)$ & $0.96(0.75,1.24)$ & $0.96(0.75,1.24)$ \\
\hline PAK & $0.98 \quad(0.76,1.31)$ & $1.04(0.88,1.30)$ & $1.04(0.86,1.29)$ \\
\hline PAN & $0.75(0.50,1.15)$ & $0.87 \quad(0.67,1.21)$ & $0.85(0.57,1.21)$ \\
\hline PAR & $1.05 \quad(0.82,1.37)$ & $1.14(0.92,1.43)$ & $1.14(0.91,1.43)$ \\
\hline PER & $1.10(0.96,1.30)$ & $1.06(0.89,1.28)$ & $1.06(0.91,1.28)$ \\
\hline $\mathrm{PHI}$ & $1.12(0.92,1.45)$ & $1.23(1.04,1.53)$ & $1.22(1.03,1.51)$ \\
\hline POL & $1.02(0.88,1.25)$ & $1.17(1.01,1.45)$ & $1.17(1.01,1.44)$ \\
\hline POR & $1.18(1.02,1.40)$ & $1.26(1.22,1.45)$ & $1.25(1.11,1.44)$ \\
\hline ROM & $1.27(1.10,1.56)$ & $1.50 \quad(1.27,1.93)$ & $1.48(1.27,1.90)$ \\
\hline RWA & $1.13(0.96,1.37)$ & $1.16(0.97,1.44)$ & $1.17(0.97,1.45)$ \\
\hline SAINL & $0.77(0.58,1.08)$ & $0.87 \quad(0.72,1.14)$ & $0.86(0.68,1.14)$ \\
\hline SILE & $0.87 \quad(0.71,1.10)$ & $0.74 \quad(0.55,1.05)$ & $0.73(0.51,1.05)$ \\
\hline
\end{tabular}

(cont.) 


\begin{tabular}{|c|c|c|c|}
\hline Country & No det. terms & With an intecept & With a linear trend \\
\hline SOM & $0.69(0.54,0.89)$ & $0.61(0.46,0.82)$ & $0.63(0.49,0.83)$ \\
\hline SPA & $1.16(0.96,1.42)$ & $1.28(1.12,1.49)$ & $1.27(1.12,1.48)$ \\
\hline SRI & $1.00(0.84,1.33)$ & $0.89(0.80,1.04)$ & $0.88(0.77,1.06)$ \\
\hline SWE & $1.01 \quad(0.87,1.21)$ & $0.97(0.81,1.18)$ & $0.97 \quad(0.82,1.18)$ \\
\hline SWI & $0.93(0.76,1.17)$ & $1.02(0.80,1.38)$ & $1.02 \quad(0.82,1.37)$ \\
\hline SYR & $0.84 \quad(0.62,1.11)$ & $0.95(0.79,1.16)$ & $0.95(0.77,1.16)$ \\
\hline THA & $1.10(0.92,1.41)$ & $1.14(0.95,1.46)$ & $1.15 \quad(0.92,1.47)$ \\
\hline TOGO & $0.76 \quad(0.67,0.90)$ & $0.78 \quad(0.69,0.92)$ & $0.73(0.61,0.90)$ \\
\hline TUN & $0.65 \quad(0.58,0.78)$ & $0.73(0.66,0.83)$ & $0.51 \quad(0.33,0.74)$ \\
\hline TUR & $0.64 \quad(0.57,0.83)$ & $0.72(0.64,0.83)$ & $0.51(0.35,0.74)$ \\
\hline UGA & $1.14(1.01,1.33)$ & $1.13(0.99,1.32)$ & $1.13(0.99,1.33)$ \\
\hline UK & $0.93 \quad(0.77,1.16)$ & $0.97(0.78,1.23)$ & $0.97(0.77,1.23)$ \\
\hline US & $1.00(0.85,0.23)$ & $1.19(1.02,1.46)$ & $1.19(1.02,1.43)$ \\
\hline VEN & $0.86 \quad(0.71,1.06)$ & $0.89 \quad(0.74,1.07)$ & $0.89 \quad(0.75,1.07)$ \\
\hline VIE & $1.24(1.11,1.48)$ & $1.26(1.13,1.49)$ & $1.27(1.14,1.50)$ \\
\hline YEM & $0.64 \quad(0.51,0.86)$ & $0.62(0.51,0.78)$ & $0.56(0.42,0.76)$ \\
\hline ZIM & $0.86 \quad(0.73,1.05)$ & $0.81(0.68,0.99)$ & $0.81 \quad(0.68,0.99)$ \\
\hline
\end{tabular}

The values in parenthesis are the $95 \%$ confidence bands for the values of $d$ where the null hypothesis (4) cannot be rejected. The values in bold refers to the selected specification for the deterministic terms. 
Table 2: Estimated coefficients for the selected models

\begin{tabular}{|c|c|c|c|}
\hline Country & d (95\% band) & Intecept (t-value) & Time trend (t-value) \\
\hline AFG & $1.21 \quad(1.03,1.46)$ & $0.02644 \quad(1.97)$ & --- \\
\hline ALB & $1.22(1.04,1.48)$ & $0.50001 \quad(6.52)$ & --- \\
\hline ANG & $1.07 \quad(0.85,1.37)$ & --- & --- \\
\hline ARG & $1.00(0.81,1.27)$ & $0.82184 \quad(9.83)$ & -- \\
\hline AUS & $1.11(0.90,1.40)$ & $2.99857 \quad(17.55)$ & --- \\
\hline AUSTRIA & $0.83 \quad(0.62,1.13)$ & $1.66004 \quad(8.65)$ & $0.04418 \quad(3.02)$ \\
\hline BAR & $0.68 \quad(0.51,0.89)$ & $0.59954 \quad(2.48)$ & $0.03705 \quad(3.09)$ \\
\hline BEL & $0.97 \quad(0.80,1.20)$ & $3.32139 \quad(13.40)$ & --- \\
\hline BEN & $1.04(0.84,1.38)$ & $0.04484 \quad(2.41)$ & $0.00578 \quad(1.97)$ \\
\hline $\mathrm{BOL}$ & $0.62(0.48,0.80)$ & $0.01626 \quad(0.37)$ & $0.01187 \quad(6.25)$ \\
\hline BRA & $1.13(0.93,1.37)$ & $0.25536 \quad(6.13)$ & --- \\
\hline BUR & $0.67 \quad(0.51,0.90)$ & $0.02049 \quad(7.16)$ & --- \\
\hline BURK & $0.97 \quad(0.79,1.36)$ & $0.01343 \quad(1.57)$ & 0.00202 (1.87) \\
\hline CAM & $1.09(0.92,1.34)$ & $0.05207 \quad(5.10)$ & -- \\
\hline CAN & $1.21 \quad(1.02,1.48)$ & $3.15515 \quad(17.31)$ & -- \\
\hline CAR & $0.62(0.47,0.81)$ & $0.03496 \quad(5.31)$ & -- \\
\hline CHAD & $0.79(0.67,0.96)$ & $0.01107 \quad(3.21)$ & 0.00039 (1.71) \\
\hline CHILE & $0.99(0.86,1.22)$ & $0.58876 \quad(5.05)$ & -- \\
\hline CHINA & $1.48(1.31,1.76)$ & $0.29708 \quad(7.10)$ & -- \\
\hline $\mathrm{COL}$ & $0.93(0.73,1.21)$ & $0.34728 \quad(12.66)$ & $0.00659 \quad(2.26)$ \\
\hline CONGO & $0.69 \quad(0.57,0.87)$ & $0.12441 \quad(3.00)$ & $0.00358 \quad(1.69)$ \\
\hline CORD & $1.00(0.84,1.23)$ & $0.06897 \quad(9.11)$ & -- \\
\hline COSR & $0.46 \quad(0.29,0.69)$ & $0.30438 \quad(3.19)$ & $0.01474 \quad(4.59)$ \\
\hline COTI & $1.17(1.02,1.39)$ & $0.08873 \quad(4.32)$ & -- \\
\hline
\end{tabular}

(cont.) 


\begin{tabular}{|c|c|c|c|}
\hline Country & $\mathrm{d}(95 \%$ band $)$ & Intecept (t-value) & Time trend (t-value) \\
\hline CUBA & $1.26(1.05,1.62)$ & $0.74495 \quad(9.77)$ & -- \\
\hline DOMR & $0.90 \quad(0.67,1.23)$ & $0.19877 \quad(3.35)$ & $0.01323 \quad(2.32)$ \\
\hline $\mathrm{DEN}$ & $1.02(0.85,1.33)$ & $3.18747 \quad(12.04)$ & -- \\
\hline ESAL & $0.92(0.81,1.12)$ & $0.15120 \quad(4.13)$ & - \\
\hline FIJ & $0.65(0.45,0.90)$ & 0.27340 & $0.01106 \quad(2.83)$ \\
\hline FRA & $1.08(0.90,1.31)$ & $2.12479 \quad(12.62)$ & -- \\
\hline GAM & $0.74(0.55,1.03)$ & $0.05678 \quad(2.39)$ & $0.00344 \quad(2.49)$ \\
\hline GER & $1.10(0.95,1.33)$ & $2.57611 \quad(10.41)$ & -- \\
\hline GHA & $0.83(0.69,1.04)$ & $0.14931 \quad(5.43)$ & 0.00416 (1.98) \\
\hline GRE & $1.11(0.96,1.30)$ & 0.53227 (2.69) & -- \\
\hline GUA & $0.62(0.33,1.01)$ & $0.46490 \quad(3.32)$ & $0.05961 \quad(9.84)$ \\
\hline GUI & $0.92(0.76,1.23)$ & $0.07101 \quad(5.24)$ & -- \\
\hline GUY & $0.86(0.71,1.07)$ & $0.70241 \quad(5.28)$ & -- \\
\hline HAI & $0.56(0.34,0.87)$ & $0.03958 \quad(5.36)$ & $0.00175 \quad(6.15)$ \\
\hline IND & $1.29(1.19,1.43)$ & $0.08776 \quad(10.00)$ & $0.00918 \quad(2.70)$ \\
\hline INDO & $0.75(0.60,0.98)$ & 0.02670 & $0.01049 \quad(9.04)$ \\
\hline ISR & $0.90(0.49,1.78)$ & $1.21613 \quad(5.27)$ & $0.04081 \quad(1.84)$ \\
\hline ITA & $1.18(1.02,1.41)$ & $0.99786 \quad(7.19)$ & -- \\
\hline JAP & $1.20(1.03,1.44)$ & $1.14822 \quad(7.23)$ & -- \\
\hline JOR & $0.91(0.71,1.26)$ & $0.46316 \quad(4.68)$ & - \\
\hline KDPR & $1.23(1.11,1.40)$ & 0.62001 & -- \\
\hline $\mathrm{KEN}$ & $0.98(0.79,1.24)$ & 0.11235 & -- \\
\hline KOR & $0.77(0.60,0.99)$ & $0.12811 \quad(0.67)$ & $0.07966 \quad(6.61)$ \\
\hline LAO & $0.52(0.26,0.87)$ & 0.05959 & $0.00140 \quad(2.82)$ \\
\hline LEB & $1.02(0.82,1.30)$ & 0.67929 (3.99) & -- \\
\hline LIB & $0.77(0.60,1.03)$ & $0.12384 \quad(3.02)$ & -- \\
\hline LUX & $0.72(0.56,0.93)$ & $10.93938 \quad(15.70)$ & -- \\
\hline
\end{tabular}

(cont.) 


\begin{tabular}{|c|c|c|c|}
\hline Country & d (95\% band) & Intecept (t-value) & Time trend (t-value) \\
\hline MAD & $0.49 \quad(0.32,0.81)$ & $0.06107 \quad(8.00)$ & -- \\
\hline MAL & $0.75(0.60,0.97)$ & $-0.02357 \quad(-0.15)$ & 0.05109 (5.59) \\
\hline MALI & $1.00(0.86,1.20)$ & $0.02546 \quad(3.98)$ & $0.00248 \quad(2.85)$ \\
\hline MALTA & $0.86(0.74,1.02)$ & $0.70984 \quad(1.82)$ & -- \\
\hline MEX & $0.33(0.16,0.55)$ & $0.49074 \quad(4.37)$ & $0.02424 \quad(6.99)$ \\
\hline MOZ & $0.75(0.64,0.90)$ & $0.09055 \quad(4.29)$ & -- \\
\hline MYAN & $1.49(0.59,1.94)$ & $0.04760 \quad(5.17)$ & -- \\
\hline NEP & $0.77 \quad(0.64,0.95)$ & $0.00664 \quad(0.64)$ & $0.00330 \quad(5.02)$ \\
\hline NETH & $0.77 \quad(0.58,1.01)$ & $2.60961 \quad(7.81)$ & -- \\
\hline NIC & $0.66(0.48,0.88)$ & $0.17621 \quad(4.62)$ & $0.00497 \quad(2.75)$ \\
\hline NIG & $0.88 \quad(0.76,1.04)$ & $0.02684 \quad(3.87)$ & $0.00109 \quad(1.75)$ \\
\hline NIGE & $1.21 \quad(0.97,1.57)$ & 0.04228 (1.94) & -- \\
\hline NOR & $0.96(0.75,1.24)$ & $2.10637 \quad(5.02)$ & -- \\
\hline PAK & $1.04(0.86,1.29)$ & $0.08604 \quad(8.32)$ & $0.00460 \quad(2.83)$ \\
\hline PAN & $0.87(0.67,1.21)$ & $0.29917 \quad(2.30)$ & -- \\
\hline PAR & $1.14 \quad(0.92,1.43)$ & $0.13417 \quad(3.28)$ & -- \\
\hline PER & $1.06(0.89,1.28)$ & $0.12691 \quad(2.96)$ & -- \\
\hline PHI & $1.23(1.04,1.53)$ & $0.13652 \quad(6.09)$ & -- \\
\hline POL & $1.17(1.01,1.45)$ & $2.26959 \quad(13.28)$ & -- \\
\hline POR & $1.26(1.22,1.45)$ & $0.33385 \quad(3.22)$ & -- \\
\hline ROM & $1.50(1.27,1.93)$ & $0.93291 \quad(8.14)$ & -- \\
\hline RWA & $1.16(0.97,1.44)$ & $0.01014 \quad(2.31)$ & -- \\
\hline SAINL & $0.86(0.68,1.14)$ & $0.27613 \quad(2.14)$ & $0.01972 \quad(1.82)$ \\
\hline SILE & $0.74 \quad(0.55,1.05)$ & $0.10701 \quad(6.81)$ & -- \\
\hline
\end{tabular}

(cont.) 


\begin{tabular}{|c|c|c|c|}
\hline Country & $\mathrm{d}(95 \%$ band $)$ & Intecept (t-value) & Time trend (t-value) \\
\hline $\mathrm{SOM}$ & $0.61(0.46,0.82)$ & $0.03824 \quad(5.53)$ & -- \\
\hline SPA & $1.28(1.12,1.49)$ & $0.77370 \quad(5.52)$ & -- \\
\hline SRI & $0.88 \quad(0.77,1.06)$ & $0.18125 \quad(5.97)$ & $0.00843 \quad(3.09)$ \\
\hline SWE & $0.97 \quad(0.81,1.18)$ & $2.51348 \quad(9.57)$ & -- \\
\hline SWI & $1.02(0.80,1.38)$ & $2.44581 \quad(12.03)$ & - \\
\hline SYR & $0.95(0.79,1.16)$ & $0.21104 \quad(2.69)$ & -- \\
\hline THA & $1.10(0.92,1.41)$ & -- & -- \\
\hline TOGO & $0.73(0.61,0.90)$ & $0.03501 \quad(1.67)$ & $0.00437 \quad(3.68)$ \\
\hline TUN & $0.51(0.33,0.74)$ & $0.05873 \quad(1.58)$ & $0.01892 \quad(14.28)$ \\
\hline TUR & $0.51(0.35,0.74)$ & 0.20972 (3.19) & $0.03110 \quad(13.24)$ \\
\hline UGA & $1.13(0.99,1.32)$ & $0.01584 \quad(2.78)$ & -- \\
\hline UK & $0.97 \quad(0.78,1.23)$ & $3.84158 \quad(20.32)$ & -- \\
\hline US & $1.19(1.02,1.46)$ & $5.09345 \quad(19.97)$ & -- \\
\hline VEN & $0.89(0.75,1.07)$ & $0.24906 \quad(1.44)$ & $0.02986 \quad(1.86)$ \\
\hline VIE & $1.26(1.13,1.49)$ & $0.07068 \quad(2.91)$ & -- \\
\hline YEM & $0.56 \quad(0.42,0.76)$ & $0.11249 \quad(2.31)$ & $0.00599 \quad(3.20)$ \\
\hline ZIM & $0.81 \quad(0.68,0.99)$ & $0.36168 \quad(6.63)$ & -- \\
\hline
\end{tabular}

The values in parenthesis in the second column are the values of $\mathrm{d}$ where the null hypothesis cannot be rejected at the 5\% level. The values in parenthesis in the third and fourth columns are the corresponding t-values. Thus, values above 1.645 indicate significance at the $5 \%$ level. 
Table 3: List of countries with significant time trend coefficients

\begin{tabular}{|l|l|l|}
\hline Country & Economic group & Estimated time trend \\
\hline South Korea & 1 & $0.07966 \quad(6.61)$ \\
\hline Guadeloupe & 1 & $0.05961 \quad(9.84)$ \\
\hline Malaysia & 2 & $0.05109 \quad(5.59)$ \\
\hline Austria & 1 & $0.04418 \quad(3.02)$ \\
\hline Israel & 1 & $0.04081 \quad(1.84)$ \\
\hline Barbados & 1 & $0.03705 \quad(3.09)$ \\
\hline Turkey & 2 & $0.03110 \quad(13.24)$ \\
\hline Venezuela & 2 & $0.02986 \quad(1.86)$ \\
\hline Mexico & 2 & $0.02424 \quad(6.99)$ \\
\hline Saint Lucia & 2 & $0.01972 \quad(1.82)$ \\
\hline Tunisia & 3 & $0.01892 \quad(14.28)$ \\
\hline Costa Rica & 2 & $0.01474 \quad(4.59)$ \\
\hline Dominican Rep. & 2 & $0.01323 \quad(2.32)$ \\
\hline Bolivia & 3 & $0.01187 \quad(6.25)$ \\
\hline Fiji & 2 & $0.01106 \quad(2.83)$ \\
\hline Indonesia & 3 & $0.01049 \quad(9.04)$ \\
\hline India & 3 & $0.00918 \quad(2.70)$ \\
\hline Sri Lanka & 3 & $0.00843 \quad(3.09)$ \\
\hline Colombia & 2 & $0.00659 \quad(2.26)$ \\
\hline Yemen & 3 & $0.00599 \quad(3.20)$ \\
\hline Benin & 4 & $0.00578 \quad(1.97)$ \\
\hline Nicaragua & 3 & $0.00497 \quad(2.75)$ \\
\hline Togo & 4 & $0.00460 \quad(2.83)$ \\
\hline Ghana & 3 & $0.00437 \quad(3.68)$ \\
\hline Pakistan & 3 & $0.00416 \quad(1.98)$ \\
\hline Congo & 3 & $0.00358 \quad(1.69)$ \\
\hline Gambia & 4 & $0.00344 \quad(2.49)$ \\
\hline Nepal & 4 & $0.00330 \quad(5.02)$ \\
\hline Mali & 4 & $0.00248 \quad(2.85)$ \\
\hline Burkina Faso & $0.00202 \quad(1.87)$ \\
\hline Haiti & $0.00175 \quad(6.15)$ \\
\hline Laos & $0.00140 \quad(2.82)$ \\
\hline Niger & $0.00109 \quad(1.75)$ \\
\hline Chad & $0.00039 \quad(1.71)$ \\
\hline Tar
\end{tabular}

The values in parenthesis in the third and fourth REMOVE!!!colums are the corresponding t-values. Values above 1.645 indicate significance at the $5 \%$ level. 
Table 4: Classification of countries according to the estimates of $\mathbf{d}$

\begin{tabular}{|c|c|c|}
\hline Evidence of $\mathrm{I}(\mathrm{d}, \mathrm{d}<1)$ & Evidence of I(1) - UR & Evidence of $\mathrm{I}(\mathrm{d}, \mathrm{d}>1)$ \\
\hline (Mean Reversion) & (Unit root behaviour) & (Explosive behaviour) \\
\hline $\begin{array}{l}\text { Mexico (0.33) } \\
\text { Costa Rica (0.46) } \\
\text { Madagascar }(0.49) \\
\text { Tunisia, Turkey (0.51) } \\
\text { Laos }(0.52) \\
\text { Haiti, Yemen (0.56) } \\
\text { Somalia (0.61) } \\
\text { Nicaragua (0.66) } \\
\text { Barbados (0.68) } \\
\text { Bolivia, Central African } \\
\text { Republic (0.62) } \\
\text { Fiji (0.65) } \\
\text { Burundi (0.67) } \\
\text { Congo (0.69) } \\
\text { Luxembourg (0.72) } \\
\text { Togo (0.73) } \\
\text { Indonesia, Malaysia, } \\
\text { Mozambique (0.75) } \\
\text { Korea, Nepal (0.77) } \\
\text { Chad (0.79) } \\
\text { Zimbawe (0.81) }\end{array}$ & $\begin{array}{l}\text { Guadeloupe (0.62) } \\
\text { Gambia, Sierra Leone } \\
(0.74) \\
\text { Liberia, Netherlands (0.77) } \\
\text { Austria, Ghana (0.83) } \\
\text { Guyana, Malta, Saint } \\
\text { Lucia (0.86) } \\
\text { Panama (0.87) } \\
\text { Niger, Sri Lanka (0.88) } \\
\text { Venezuela (0.89) } \\
\text { Dominican Republic, } \\
\text { Israel (0.90) } \\
\text { Jordan (0.91) } \\
\text { El Salvador, Guinea (0.92) } \\
\text { Colombia (0.93) } \\
\text { Syria (0.95) } \\
\text { Norway (0.96) } \\
\text { Belgica, Burkina Faso, } \\
\text { Sweden, U.K. (0.97) } \\
\text { Kenya (0.98) } \\
\text { Chile (0.99) } \\
\text { Argentina, Democratic } \\
\text { Rep. of Congo, Mali } \\
\text { (1.00) } \\
\text { Denmark, Lebanon, } \\
\text { Switzerland (1.02) } \\
\text { Benin, Pakistan (1.04) } \\
\text { Peru (1.06) } \\
\text { Angola (1.07) } \\
\text { France (1.08) } \\
\text { Cameroon (1.09) } \\
\text { Germany, Thailand (1.10) } \\
\text { Australia, Greece (1.11) } \\
\text { Brazil, Uganda (1.13) } \\
\text { Paraguay (1.14) } \\
\text { Rwanda (1.16) } \\
\text { Nigeria (1.21) } \\
\text { Myanmar (1.49) }\end{array}$ & $\begin{array}{l}\text { Cote d'Ivoire, Poland } \\
(1.17) \\
\text { Italia (1.18) } \\
\text { U.S. (1.19) } \\
\text { Japan (1.20) } \\
\text { Afganistan, Canada (1.21) } \\
\text { Albania (1.22) } \\
\text { North Korea, Phillippines } \\
(1.23) \\
\text { Cuba, Portugal, Vietnam } \\
\text { (1.26) } \\
\text { Spain (1.28) } \\
\text { India (1.29) } \\
\text { China (1.48) } \\
\text { Romania (1.50) }\end{array}$ \\
\hline Countries in group 1: & Countries in group 1: 15 & Countries in group 1: \\
\hline Countries in group 2: & Countries in group 2: 13 & Countries in group 2: \\
\hline Countries in group 3: & Countries in group 3 : & Countries in group 3: \\
\hline Countries in group 4: 10 & Countries in group 4: & Countries in group 4: \\
\hline
\end{tabular}

This classification is based on the statistical significance provided by the confidence bands in Table 2 . 
Appendix 1: Abbrevations of countries

\begin{tabular}{|c|c|c|}
\hline $\begin{array}{l}\text { AFG = Afganistan } \\
\text { ALB = Albania } \\
\text { ANG = Angola } \\
\text { ARG = Argentina } \\
\text { AUS = Australia } \\
\text { AUSTRIA = Austria } \\
\text { BAR = Barbados } \\
\text { BEL = Belgium } \\
\text { BEN = Benin } \\
\text { BOL = Bolivia } \\
\text { BRA = Brazil } \\
\text { BUR = Burundi } \\
\text { BURK = Burkina Faso } \\
\text { CAM = Cameroon } \\
\text { CAN = Canada } \\
\text { CAR = Central Africa Rep. } \\
\text { CHAD = Chad } \\
\text { CHILE = Chile } \\
\text { CHINA = China } \\
\text { COL = Colombia } \\
\text { CONGO = Congo } \\
\text { CORD = Dem } . \text { Rep. Congo } \\
\text { COSR = Costa Rica } \\
\text { COTI = Cote d'Ivorie } \\
\text { CUBA = Cuba } \\
\text { DOMR = Dominican Rep. } \\
\text { DEN = Denmark } \\
\text { ESAL = El Salvador } \\
\text { FIJ = Fiji } \\
\text { FRA = France } \\
\text { GAM = Gambia } \\
\text { GER = Germany }\end{array}$ & $\begin{array}{l}\text { GHA = Ghana } \\
\text { GRE = Greece } \\
\text { GUA = Guadeloupe } \\
\text { GUI = Guinea } \\
\text { GUY = Guyana } \\
\text { HAI = Haiti } \\
\text { IND = India } \\
\text { INDO = Indonesia } \\
\text { ISR = Israel } \\
\text { ITA = Italia } \\
\text { JAP = Japan } \\
\text { JOR = Jordan } \\
\text { KDPR = Korean Dem. P. Rep. } \\
\text { KEN = Kenya } \\
\text { KOR = Korea } \\
\text { LAO = Laos } \\
\text { LEB = Lebanon } \\
\text { LIB = Liberia } \\
\text { LUX = Luxembour } \\
\text { MAD = Madagascar } \\
\text { MAL = Malaysia } \\
\text { MALI = Mali } \\
\text { MALTA = Malta } \\
\text { MEX = Mexico } \\
\text { MOZ = Mozambique } \\
\text { MYAN = Myanmar } \\
\text { NEP = Nepal } \\
\text { NETH = Netherlands } \\
\text { NIC = Nicaragua } \\
\text { NIG = Niger } \\
\text { NIGE = Nigeria } \\
\text { NOR = Norway }\end{array}$ & $\begin{array}{l}\text { PAK = Pakistan } \\
\text { PAN = Panama } \\
\text { PER = Peru } \\
\text { PHIL = Phillippines } \\
\text { POL = Poland } \\
\text { POR = Portugal } \\
\text { ROM = Romania } \\
\text { RWA = Rwanda } \\
\text { SAINL = Saint Lucia } \\
\text { SILE = Sierra Leone } \\
\text { SOM = Somalia } \\
\text { SPA = Spain } \\
\text { SRI = Sri Lanka } \\
\text { SWE = Sweden } \\
\text { SWI = Switzerland } \\
\text { SYR = Syria } \\
\text { THA = Thailand } \\
\text { TOGO = Togo } \\
\text { TUN = Tunisia } \\
\text { TUR = Turkey } \\
\text { UGA = Uganda } \\
\text { UK = United Kingdom } \\
\text { US = United States } \\
\text { VEN = Venezuela } \\
\text { VIE = Vietnam } \\
\text { YEN = Yemen } \\
\text { ZIM = Zimbawe }\end{array}$ \\
\hline
\end{tabular}


Appendix 2: Classification of countries according to the income level

\begin{tabular}{|c|c|c|c|}
\hline $\begin{array}{l}\text { High income } \\
\text { (1) }\end{array}$ & $\begin{array}{l}\text { Upper-middle } \\
\text { income (2) }\end{array}$ & $\begin{array}{l}\text { Lower-middle } \\
\text { income (3) }\end{array}$ & $\begin{array}{c}\text { Low income } \\
\text { (4) }\end{array}$ \\
\hline $\begin{array}{l}\text { Australia } \\
\text { Austria } \\
\text { Barbados } \\
\text { Belgium } \\
\text { Canada } \\
\text { Chile } \\
\text { Denmark } \\
\text { France } \\
\text { Germany } \\
\text { Greece } \\
\text { Guadaeloupe } \\
\text { Israel } \\
\text { Italy } \\
\text { Japan } \\
\text { Korea } \\
\text { Luxembourg } \\
\text { Malta } \\
\text { Netherlands } \\
\text { Norway } \\
\text { Poland } \\
\text { Portugal } \\
\text { Spain } \\
\text { Sweden } \\
\text { Switzerland } \\
\text { UK } \\
\text { US }\end{array}$ & $\begin{array}{l}\text { Albania } \\
\text { Argentina } \\
\text { Brazil } \\
\text { China } \\
\text { Colombia } \\
\text { Costa Rica } \\
\text { Cuba } \\
\text { Dominican Rep. } \\
\text { Fiji } \\
\text { Guyana } \\
\text { Lebanon } \\
\text { Malaysia } \\
\text { Mexico } \\
\text { Panama } \\
\text { Paraguay } \\
\text { Peru } \\
\text { Romania } \\
\text { Saint Lucia } \\
\text { Thailand } \\
\text { Turkey } \\
\text { Venezuela }\end{array}$ & $\begin{array}{l}\text { Angola } \\
\text { Bolivia } \\
\text { Cameroon } \\
\text { Congo } \\
\text { Cote d'Ivorie } \\
\text { El Salvador } \\
\text { Ghana } \\
\text { India } \\
\text { Indonesia } \\
\text { Jordan } \\
\text { Kenya } \\
\text { Laos } \\
\text { Myanmar } \\
\text { Nicaragua } \\
\text { Nigeria } \\
\text { Pakistan } \\
\text { Phillipinnes } \\
\text { Sri Lanka } \\
\text { Syria } \\
\text { Tunisia } \\
\text { Vietnam } \\
\text { Yemen }\end{array}$ & $\begin{array}{l}\text { Afganistan } \\
\text { Benin } \\
\text { Burkina Faso } \\
\text { Burundi } \\
\text { Central African Rep. } \\
\text { Chad } \\
\text { Congo Dem. Rep. } \\
\text { Gambia } \\
\text { Guinea } \\
\text { Haiti } \\
\text { Korean Dem. Pop. R. } \\
\text { Liberia } \\
\text { Madagascar } \\
\text { Mali } \\
\text { Mozambique } \\
\text { Nepal } \\
\text { Niger } \\
\text { Rwanda } \\
\text { Sierra Leone } \\
\text { Somalia } \\
\text { Thogo } \\
\text { Uganda } \\
\text { Zimbawe }\end{array}$ \\
\hline
\end{tabular}

